Article

\title{
From Marx to Heidegger: Oscar del Barco and the crisis of Marxism
}

\author{
Bruno Bosteels \\ Department of Latin American and Iberian Cultures, Columbia University, New York, USA; \\ bb438@columbia.edu
}

Submission date: 8 April 2021; Acceptance date: 14 November 2021; Publication date: 7 December 2021

\section{How to cite}

Bosteels, B. 'From Marx to Heidegger: Oscar del Barco and the crisis of Marxism'. Radical Americas 6, 1 (2021): 21. DOI: https://doi.org/10.14324/111.444.ra.2021.v6.1.021.

\section{Peer review}

This article has been peer-reviewed through the journal's standard double-blind peer review, where both the reviewers and authors are anonymised during review.

\section{Copyright}

2021, Bruno Bosteels. This is an open-access article distributed under the terms of the Creative Commons Attribution Licence (CC BY) 4.0 https://creativecommons.org/licenses/by/4.0/, which permits unrestricted use, distribution and reproduction in any medium, provided the original author and source are credited • DOI: https://doi.org/10.14324/111.444.ra.2021.v6.1.021.

\section{Open access}

Radical Americas is a peer-reviewed open-access journal.

\begin{abstract}
This article traces the path from Marx to Heidegger along which the Argentine philosopher Oscar del Barco responded to the crisis of Marxism. Interrogating Heidegger's own suggestion of a 'fruitful dialogue' with Marx's thinking of history and alienation, Del Barco gradually moved to a critique of Marxism as being part and parcel of the twice millenarian tradition of Western metaphysics. If, in an earlier collection such as El otro Marx, he still believed in the possibility of retrieving the 'other side' of capitalist reason in the margins of Marx's texts, starting in the collection El abandono de las palabras this hope gives way to a mystical or messianic expectation to welcome the sheer 'there is' of being through an attitude of non-doing that would be neither nihilist nor conformist. In this sense Del Barco's itinerary can be considered paradigmatic of the way in which a whole school of radical theory and philosophy responded to the crisis of Marxism as part of a much vaster, epochal or civilisational crisis of reason and technology in the West.
\end{abstract}

Keywords Oscar del Barco; Karl Marx; Martin Heidegger; Marxism; crisis; metaphysics; nihilism; poetry; revolution; materialism 


\section{Introduction}

Sometimes behind the superficial appearance of a simple change in intellectual fashions there lurks a much more profound transformation, rooted in vast social, cultural and political displacements. Undoubtedly, this is the case of the fate of references to Marx after the most recent in a long series of crises in the chronicle of Marxism's foretold death, the one that Louis Althusser forcefully declared at the conference of 1977 in Venice organised by the Italian newspaper II Manifesto on the subject of 'post-revolutionary society': 'We must not be afraid to use the phrase: it is clear from many signs that today Marxism is once again in crisis, and that this crisis is an open one. ${ }^{1}$ In Latin America, to be sure, we need not wait for Althusser's oracular word to become aware of the fact that Marxism was at last, or once again, in crisis. The evidence is overwhelming and takes the form of military coups, dirty wars and the violent repression of urban and peasant guerrilla movements. Thus, the defeat of the socialist and communist Left in the 1970s imposed the task of a self-critique, if it did not condemn the militants directly to silence and death. This is why there is no need to wait for Althusser in order for the Latin American Left to awaken to the crisis. And yet, given the outsized relevance that the thought of this French Marxist and author of For Marx and Reading Capital had acquired in the region, it is nevertheless possible after Althusser's pronouncements in Italy to perceive a noticeable increase in the number and intensity of discussions about the crisis of Marxism in Latin America.

In Mexico, for instance, the Argentine philosopher, poet and painter Oscar del Barco, who at the time was living in exile in Puebla, edited a volume in 1979 called La crisis del marxismo (The Crisis of Marxism), as if to amplify the hypotheses of his own book, Esbozo de una crítica a la teoría y práctica leninistas (Outline for a Critique of Leninist Theory and Practice). And in the journal Controversia, also edited in Mexico by a group of Argentine exiles, this crisis as well as the critique of Marxism-Leninism constituted one of the principal polemical axes, together with the experience of defeat that the revolutionary Left had suffered with the military coup of March 1976 in their home country. According to Del Barco, it was important to underscore that the crisis of Marxism was not only theoretical, as Althusser's analysis and response might suggest. In fact, in his intervention at the conference of II Manifesto the French philosopher had indicated that the crisis opened the possibility of revisiting the study of two major lacunae left behind not only by Marx but also by later thinkers such as Lenin. Althusser writes:

It is in this profoundly political sense that we are forced today, it seems to me, to speak of a theoretical crisis within Marxism, in order to clarify the ways in which it affects what is called Marxist theory itself: and in particular the fact that a number of apparently infallible principles inherited from the Second and Third Internationals have now been placed in doubt. ${ }^{2}$

And, in order to exemplify the fact that these theoreticians of the workers' movement would not have bequeathed us a unified corpus of theory but instead a work full of contradictions and gaps, Althusser goes on to mention two gaps in particular in the political theory of Marxism: 'There exist in Marx and Lenin two theoretical gaps of great importance: on the one hand on the State, on the other hand on the organizations of class struggle. ${ }^{3}$ Insofar as these theoretical gaps also open up important strategic questions, for Althusser it was urgent to respond to them with rectifications that would be adjusted to the specific conditions of the crisis so as to meet the demands of the actuality of Marx's original discourse.

For Oscar del Barco, on the other hand, the crisis of Marxism is not only theoretical, or at least not in the first place. Moreover, to respond to the crisis with a series of rectifications and adjustments that are once again theoretical means running the risk of losing sight of the radical gesture that produce Marx's work. It would be a stubborn way of making the same mistake over and over again, by continuing to make turns within the epistemological circle of theory. It is necessary, therefore, to proceed in some other way, both in the evaluation of the original gesture behind Marx's thought and in the conjunctural analysis of the crisis of Marxism.

\section{Towards The Other Marx}

Thus, in a collection of essays first published in 1983 during his exile in Puebla under the title El otro Marx (The Other Marx), Del Barco proposes to focus on those other or strange aspects of the author of Capital: aspects that precisely resist being incorporated into a complete 'opus', a philosophical 'system' 
or a 'discourse on method' typically required in the manuals of Marxism-Leninism, but instead can be found dispersed in multiple unpublished manuscripts, incomplete fragments, or marginal notes.

To follow the tracks of this 'other' Marx requires the talent of a kind of gaucho rastreador, or track-finder: 'It is a question of following the tracks; tracking the unstable forms of a fleeting power, the tracks of which demand abilities of sight, smell, and speed never before put into practice in any kind of "epistemology".'4 These qualities of sight, smell and speed are indispensable, because the task consists in tracing a fleeting, dispersed and stubborn form of knowledge, similar to the knowledge of the unconscious in Freud. As the author of El otro Marx adds, 'this knowledge [saber], in the proper sense, is aimed at a reality that can only be approached through the remainders and fractures, the slippages, the fissures and the leftovers of what for so long, at least on the front stage of history, was believed to be something compact and legal, a strict objectivity structured according to the canons of Reason'. ${ }^{5}$ However, through such traces, slippages and leftovers, what is at stake above all is a subjective disposition that sinks its feet in the subsoil of the non-theoretical. This is because for Del Barco Marx's thought marks such a fundamental rupture in the self-grounding circle of theory or philosophy - the circle of post-Hegelian Western reason - that any attempt to reinsert it into this circle at the time of responding to the crisis of Marxism only further augments the level and intensity of the mistake.

For Del Barco, all those philosophers who attempt to reduce Marx's rupture with regard to philosophy, or his distancing from Hegel, to a purely 'theoretical revolution' (as in the title of the Spanish translation of Althusser's Pour Marx, published as La revolución teórica de Marx), lose sight of the fact that the very form of the theoretical in Marx necessarily has its basis in an element of the non-theoretical. This is the original idea behind the texts collected in the volume El otro Marx, which in 2008 was reissued in a reduced version in Argentina: the other Marx, which also means the other side of Marx, names this irreducible remainder without which no theory whatsoever would be possible, nor any critique. A non-theoretical element constitutes the reverse side of every critical theory, but this reverse also constitutes the leverage with which the theoretical can be broken and opened up to its outside, dislocating it from within towards a beyond of pure theory or philosophy: 'This trans-theoretical movement produces an absolute displacement of the philosophical corpus. ${ }^{6}$

The other side of Marx, in this sense, is the other or obverse of theory: nature, living labour, struggle, love, the body, poetry, painting, art; but, also, everything unthought and repressed by capitalist society:

The other, the unthought of this society, is the repressed: poverty, the Third World, madness, delinquency, suicide, the proletariat as class in-itself (let us say that as class for-itself the proletariat raises numerous questions that are the result of historical experience, in the extent to which it turns itself into a new Logos, a new Law, whereas in terms of class in-itself it is a class dominated by death: wildcat strikes, revolts, forms of resistance that are rooted in hatred and not in theory). ${ }^{7}$

Here, in this accursed share of the other of the system, there resides finally the only absolute - without hypostasis or large capitals - for the author. And there is no need to hold on to the prestige of the corpus of Western philosophy accredited by the discourse of the university in order to denigrate these other or uncanny dimensions of life, either because for Marxist intellectuals of the Althusserian stripe, as Del Barco suggests, they would never appear to be sufficiently 'scientific' or 'rigorous' from the epistemological point of view; or because, as I would add in turn, for thinkers in the Heideggerian school, they would not have given way to a sufficiently 'radical' or 'originary' deconstruction of their very own ontological presuppositions.

The notion that the basis of theory is never purely or simply theoretical but fundamentally other and non-theoretical is an idea that the author of El otro Marx had anticipated in his contribution to the debate about the crisis of Marxism in Controversia, in response to a text by two Spanish thinkers, Ludolfo Paramio and Jorge M. Reverte. 'It seems to me that by situating theory as the central element of the crisis the risk is that the fundamentally political root of the problem goes up in smoke,' Del Barco wrote on that occasion. 'The crisis is not the result of a commotion internal to the theoretical order but stems from the fact that the European and non-European peoples are gaining full consciousness of the dead end street to which their own organizations were led, that is to say, they became ever more profoundly aware of their own failure. ${ }^{8}$ Not only does the crisis far exceed the strictly theoretical framework but, by proposing that the only exit from the crisis is a prior change of paradigm in the realm of theory, there is an even greater temptation of remaining trapped in a form of theoreticism. This would be the case of 
Althusser's discourse, including at the time of his famous self-criticism. 'What is erased in this discourse are the non-theoretical determinations of the theoretical crisis,' Del Barco adds.

My view, however, is that the 'theoretical crisis' cannot be explained on its own terms, but it is a global crisis in which the theoretical element cannot be isolated without running the risk of lapsing into theoreticism, which implies a double movement that splits theory from practice and then produces the conversion of theory into the social subject.?

In this double movement we can recognise the tendency towards the theological and idealist conversion of all modern European philosophy that culminates in Hegel's thinking, with its typical scission and inversion of subject into predicate and of predicate into subject, in the way it was criticised by the Young Hegelians, from Feuerbach to Marx, when they rebelled against their old teacher. ${ }^{10}$

\section{An explosion of the frame of reference}

The crisis of Marxism thus would indicate that the issue is not to solve it by means of purely theoretical rectifications that would fill the gaps left open in the founding document, but rather to break with the whole tradition of theoreticism itself:

The crisis has caused a displacement of theoreticism and installed the problematic in a different place, outside the vicious circle of epistemology. Considering the text on the basis of what Marx called the imminence of the revolutionary 'deluge', the possibility opens up to include in the interpretation of the other of the theoretical: the real in which the theoretical functions in discontinuous fashion, in a dispersion that suppresses any type of substance. ${ }^{11}$

What is more, if Marxism itself is above all an expansive practical movement, this practice need not be limited to a single sphere, not even the sphere of politics in its traditional sense. On the contrary, there is always something extra, an excess, or a plus that breaks with the pre-established determination of spheres, levels or instances, so sought after by structuralist Marxists in their endeavour to be proclaimed the authentic epistemologists of the science of history. Precisely, if it makes sense to keep talking in terms of politics in the case of a thinker such as Marx, better known for his critique of representative politics than for his concrete prescriptions for reaching communism, it will be as the effect of this plus that bores a hole in and traverses the walls with which the established power structure attempts to separate and enclose the collective practices:

Finally, we must clarify that we do not use the term politics in the sense of a closed practice within an order predetermined as political, but essentially on the basis of the endless plus that characterizes the political and that can become appropriated in any type of practice precisely by transcending the repressive closure of the specific element marked off and maintained in its specificity by the structure of power. ${ }^{12}$

In this sense, rather than define a topography of the social (with its different levels and instances of the base and superstructure), similar to the topologies of Freudian psychoanalysis (with the instances of the id, the ego and the superego), Marxism would be a fundamentally a-topical militant thought:

Marx's concepts are the expressions of a real situation and they are destined to the transformation of the real by means of the assumption of the concept by reality: Is it therefore something that can only be announced as a possibility or a myth? Insofar as it is not a factical existence, it is in effect a possibility and not something given; in sum, at issue is the myth of human equality. It is at this point, which with certain precautions can be called political, where the different layers of Marxism are articulated. The suspicions with regard to the use of the term 'political' stem from the fact that strictly speaking what is intended is not a locus where practice would be able to close itself off but rather a multiplicity of a-topical processes captured in their intensity. Marxism is never a topography but, on the contrary, the tendentially conscious transgression of every topological and ecstatic moment insofar as it is the theoretical-form of flows and is charged with an intentionality destined to produce the transgression of every stasis. ${ }^{13}$ 
If we take into account the non-theoretical but practical ground of all theory, as well as the expansive a-topical nature of political practice beyond its disciplinary confines, a careful reading of the crisis of Marxism can begin to open the frame of references with texts and names that are not strictly theoretical or philosophical. Thus, in his texts collected in El otro Marx and even more so in later collections such as El abandono de las palabras (The Abandonment of Words) and La intemperie sin fin (The Endless Distress), Del Barco proceeds on the basis of the idea that Marx can and must be read together with Nietzsche and Heidegger, that Sade or Artaud are as important as Lenin or Althusser; and that the poetry of Hölderlin or Mallarmé can teach us at least as much, if not more, about the danger and the salvation than any handbook of dialectical and historical materialism from the old Soviet Union. This is why Del Barco raises a new set of questions as a way of approaching the other Marx.

Let us state some of these questions, which, without a doubt, will strike an unusual tone to the ears accustomed to the 'stony' melody of present-day nihilism: What is the relation between the texts of Marx and those of Mallarmé (and, of course, this last name is no accident)? What is the basis for the resurgence of Nietzsche in the context of the crisis of 'Marxism', or, in other words, how can we link Marx with Nietzsche starting from a presumed intertextuality and a similar use of critique? And the decisive question with regard to what we might call the emergence of contemporary thought (I am thinking not only of Mallarmé and his era but also of Rilke, Joyce, Proust, Artaud, Schönberg and Braque, among so many others): did the proletariat as essentially a-topical and erratic class not inaugurate an original space, not only in thought but fundamentally of being? And did not the displacement of this fact on the part of theoreticism make the Marxist discourses incomprehensible as the radical negation of each and every logos? ${ }^{14}$

Del Barco is not the only one to choose this select lineage of proper names: Mallarmé, Artaud, Bataille, Nietzsche, Sade, Heidegger, Blanchot, Wittgenstein, Joyce, Proust and so on, to whom the Argentine philosopher sometimes adds the local figures of Macedonio Fernández and the poet Juan L. Ortiz. A few years after the publication of El otro Marx, the French philosopher Jean-Luc Nancy offers a similar list in his short book L'oubli de la philosophie (The Forgetting of Philosophy), in which he responds to the detractors of the so-called 'thought of "68"' in France. What this attack against Althusser, Foucault, Derrida or Lacan refuses to accept, according to Nancy, is the point of rupture that took place within the twice-millenarian frame of Western thought. This rupture is nothing less than a civilisational break, which according to Nancy can be thought in a privileged way starting from a select number of thinkers, artists and writers - though still equally as homogeneous in terms of gender as Del Barco's list - from the end of the nineteenth and the early twentieth centuries in Europe:

In our most recent history, perhaps three names are the principal witnesses to what has happened: Benjamin, Heidegger, and Wittgenstein (I understand that these names could serve both as the thoughts that they sign and as a kind of signal for the entire network of names they entail: Nietzsche and Marx, Bataille and Proust, Hölderlin and Baudelaire, Apollinaire and Joyce, Frege and Einstein, Malevitch and Webern, and many others). ${ }^{15}$

What has happened, or what was the happening, during the events of May 1968 according to Nancy goes far beyond the confines of France and signals a crisis of the entire civilisational structure of the West:

What was a happening in 1968 is still happening to us, contrary to what the doctors or guardians of the (in)significant order believe, who see in this a mere crisis that has already passed. Rarely, no doubt, since the end of Rome, has a civilization or a culture experienced to such an extent the inclinatio toward the last resources of its significations, as much in the relation of the West to itself as in its relations with the 'Third World' and the 'Fourth World'. It is indeed a crisis (of which the thoughts of the return are a symptom) - it is our crisis, the crisis of our actual history, in that it determines and judges the accomplishment of metaphysics as the will-to-signify. ${ }^{16}$

For Del Barco, though, the explosive broadening of the frame of reference to think the crisis of Marxism as part of the crisis of Western civilisation, at least in a first stage, may still be inscribed within the horizon of a form of thinking whose aim would be revolutionary praxis. As he suggests in 1977 in his book Esencia y 
apariencia en El Capital (Essence and Appearance in Capital), 'it is a question of a practice similar to the "festive" (Rousseau-Derrida), to "play" (Nietzsche), to "polymorphous perversity" (Freud), to "poetry" (Heidegger), and fundamentally, perhaps, to death. What should we call it? Today, plainly and simply put, I find no better name than that of revolutionary practice. ${ }^{17}$ Little by little, in the subsequent stages of his politico-philosophical itinerary, the same author on the contrary would go on to cast more and more doubts on his older confidence in the practice and the idea of the revolution. From Marx we thus will pass on to the ubiquitous reference to the name of Heidegger. Instead of serving the broader redefinition of revolutionary action, the festival, play, perversion, death and, above all, the language of the poets then will come to supplant the still all-too-metaphysical presuppositions behind the idea of practice as a subjective doing or producing.

This is the change of perspective that can already be noticed in the presentation of the collective volume La crisis del marxismo:

In other words, it is not only that the defeat of 'really existing socialism' would be the indispensable leverage for the understanding of the Marxist theoretical crisis, but it also serves to show that 'Marxism' alone no longer fulfills the revolutionary needs of the class, and this is why we see the emergence of a whole set of concrete theorizations that configure a new type of thinking, a thinking based on the failure, as well, of anthropocentrism, of logocentrism, etc. and that question the very possibility of the or a theory (which in its unity cannot but be form of the logos, of Knowledge, etc., that is to say, new form of metaphysics), the possibility of the or a party, the possibility of a discourse, in sum, whose structure recognizes presence as its foundation. It is these erratic, discontinuous discourses, unsublateable into the One (theoretical, political, aesthetic, etc.) that would mark the Marxism that will arise, I think necessarily, from the immense chaos that characterizes our present, and not so much the development of a Marxist 'sociology', 'economy' and 'history'; the theoretical revolution, about which Paramio and Reverte speak, beyond its own space in which it is inscribed, is the form of an experience that seeks to liberate itself, in order to become hegemonic, both from its own tradition, coagulated into 'orthodoxy', and from the metaphysical grid. ${ }^{18}$

The key word at last has been launched: what is at stake is an interminable confrontation with the tradition of metaphysics. Here the crisis of Marxism shows its true face and, consequently, we can begin to see the deeper reasons for the paradigm shift from Marx to Heidegger.

Del Barco explains where this impulse comes from that causes the whole theoretical frame of reference to explode in such a spectacular manner. If the answer to the crisis demands such a wide range of references, this is due above all to the fact that the crisis overflows the fate of Marxism alone after the failure or defeat of really existing socialisms. It affects, rather, the totality of Western discursive reason in the epochal movement of its nihilistic path in which, in the end, it hits upon its own tendency towards self-destruction. As he will say in 'Heidegger and the "Mystery" of Technology', included in El abandono de las palabras: 'The crisis, in a way, exceeds all: nobody can deny the crisis of the West, but in this sense the term "crisis" becomes pejorative and begins to signal everything that terrorizes the human being. ${ }^{19}$

On the one hand, if we remember the introductory words in the presentation of La crisis del marxismo, there is the experience of liberating oneself from the 'orthodoxy' of official Marxism. In passing, though, we may also notice that there is talk of a liberation with the ambition of becoming hegemonic. On the other hand, there is the desire to exit from the whole metaphysical 'grid', in which orthodox Marxism, or Marx's thought fixated and coagulated into 'Marxism', perhaps has remained trapped. The critique of anthropocentrism, logocentrism or productivism, then, requires a destruction or a deconstruction, more so than a revolution. This is yet another suggestion that the author had anticipated in his book Esencia y apariencia en El Capital: 'To conceive of the revolution as such, in its own movement, implies the destruction of the Western episteme, made up of a world of categories (essence, appearance, truth, being, presence) that dominate the thought of society in its entirety. ${ }^{\prime 20}$ The idea of revolutionary practice, or praxis as the transformation and not only the interpretation of the world in the words of the famous 11th of Marx's 'Theses on Feuerbach', in fact, does not escape the limited framework defined by the epochal principles of the Western reason or logos as a system that culminates in the epoch of the world image as a provocative reserve of objects arranged for the production and manipulation by the human subject. But, the dominant framework from which we really must liberate 
ourselves, this time without any hegemonic desire whatsoever, is from the modern metaphysics of the subject, or 'man' capable of producing his own essence.

Instead of looking for a definitive answer to the question of 'what is to be done?', therefore, a Heideggerian approach to the crisis of Marxism-Leninism would bring us closer and closer to a region where what reigns - without dominion or will - is pure being, not as a doing but precisely as a non-doing, or as an undoing, that is to say, as the abandonment of the subject to the letting-be of a life without why and without what for.

\section{Marx beyond Marxism: new guide for the perplexed}

The changeover from Marx to Heidegger is not the only kind of these displacements, several of which moreover are prior to the crisis of Marxism and in some cases even coincide with a moment of splendour and renovation, rather than crisis or decline, in the readings of Marx. Thus, for instance, we may think of the itinerary from Marx to Spinoza; or also of the one that goes from Marx to Machiavelli. In these cases, it is still a question of something like an internal reorientation of Marxism itself.

\section{From Marx to Spinoza}

As far as the first case is concerned, not only is it well known that Marx in his youth was a fervent reader of Spinoza, having composed in 1841 a Spinoza Notebook whose interest goes well beyond a purely philological curiosity. As the editor of the Spanish edition of Marx's notebook writes: 'It is an intellectual operation and a political intervention with enormous interest that can be understood both as a gesture of spiritual appropriation and as the construction of an effective antidote against the liberal premises proper to Hegel's thought. ${ }^{21}$ We also know that for the same reasons - to present Spinoza as the antidote against Hegel - a whole generation of Marxists especially among Althusser's disciples, from Pierre Macherey to André Tosel, found food for thought in their evaluation of the crisis of Marxism in the propositions of the author of the Theologico-Political Treatise. As their former teacher from École Normale Supérieure in rue d'Ulm and coordinator of the collective project Reading Capital used to say: 'Spinoza's philosophy introduced an unprecedented theoretical revolution in the history of philosophy, probably the greatest philosophical revolution of all time, in so far as we can regard Spinoza as Marx's only direct ancestor from the philosophical standpoint.'22 But in Latin America, too, Spinoza provided more than one generation of philosophers with a fundamental reference point for rethinking the revolution with and against Marx. As the Brazilian philosopher Marilena Chauí writes: 'We would venture to say that, just as Feuerbach offers Marx the possibility of the philosophical critique of religion, Spinoza offers him the possibility of the philosophical critique of politics. ${ }^{23}$ And today, in the wake of the crisis of Marxism, this critique is more urgent than ever.

\section{From Marx to Machiavelli}

As for the itinerary from Marx to Machiavelli, we know since at least Antonio Gramsci that there has been a constant attempt in the tradition of Western Marxism to present Marx as the Machiavelli of the proletariat and the theory of the revolutionary party as Lenin's modern Prince. A re-reading of Marx on the basis of Machiavelli, on the one hand, reveals to us something of a 'joker' or an 'included third' in the Hegelian duality of civil society and the State; and, on the other, it allows us to grasp politics in its actuality or effective truth. As Étienne Balibar writes in a text from the early 1980s: 'It is in this sense that I propose to recognize a "Machiavellian" and non-Hegelian aspect of the concept of politics in Marx', insofar as it no longer anticipates its own end in the full actualisation of society in the State: 'In this sense, though framed in quite different terms, politics is again that which exceeds the State, that which constitutes it as a temporary balance or relative relationship of forces; a process of differentiation rather than integration. ${ }^{24}$ In this same vein, however, we can also notice a tendency to use the 'Machavellian moment' of Marx as a wedge to separate the argument for a 'true democracy' in his Critique of Hegel's 'Philosophy of Right' in 1843, for example, against the dogmatic excesses of Marxism-Leninism and 'really existing socialism' in the Soviet Union. This is how the late Miguel Abensour, following the example of his mentor Claude Lefort, reads Marx in his book Democracy against the State: Marx and the Machiavellian Moment. 'From this perspective, the collapse of the Marxist regimes falsely claiming to be "socialist" 
may be seen as having, among other salutatory effects, "returned" Marx to us - a Marx freed from the rigidified ideological layers that have constituted a barrier between him and us', Abensour explains. And he adds:

This brings us back to the rift between Marx and Marxism. For it was by proposing an analysis of our contemporaneous Machiavellian moment - which may be considered as establishing itself through a critique of Marxism in order to rediscover a political realm lost either in philosophies of history or in scientistic projects - that I first became aware that an earlier Machiavellian moment already existed in Marx. ${ }^{25}$

With the reading of Machiavelli, in other words, we can observe a point where the road begins to bifurcate, possibly with irreversible effects for the comprehension of Marx. Thus, too, after his first incursions into the work of the Florentine thinker, in the early 1960s, until his return to him in the late 1970s, Althusser seeks to reorient his reading of Machiavelli in part in response to the crisis of Marxism. To the notion of immanent or absent causality that his canonical writings had borrowed from Spinoza, now Althusser adds for example an emphasis on the aleatory element in the play between fortuna and virtù according to Machiavelli. With this emphasis, which will be key for his development of an underground current of aleatory materialism of the encounter, Althusser hopes to escape the determinism that never ceased being present even in his own version of the materialist dialectic at the time of For Marx and Reading Capital. What now draws his attention is the unusual, strangely familiar or enigmatic side that he also describes under the title 'Machiavelli's Solitude', in a text from the same year in which he declared the crisis of Marxism. 'Without our knowing why, it turns out that these ancient texts interpellate us as if they were from our time and they trap us as if they had been, in a way, written for us and in order to tell us something that touches us directly, without our knowing exactly why,' Althusser indicates, speaking of The Prince and the Discourses. Even beyond the crisis of Marxism, Machiavelli's thinking launches questions that are still enigmatic to this day, such as: 'Why, as Claude Lefort has brilliantly demonstrated in his thesis, does it unfold via interruptions, digressions, unresolved contradictions? How is it that a system of thought apparently under such tight control is in fact both present and fleeting, complete and incomplete in its very manner of expression?'26 These are questions in which we can easily recognise the same concerns as the ones that drive Oscar del Barco in his attempt to track down of the otherness of the system in El otro Marx.

While thus already present in the path that takes us from Marx back to Machiavelli, the impulse to open up alternatives to the orthodox interpretation of Marx's thought - as defined in Lenin's account, for example, as the synthesis of its three 'sources' or 'component parts' that are German philosophy (Hegel), English political economy (Smith and Ricardo), and French proletarian politics (not only the utopian socialists like Proudhon but also Marx's real 'discovery' of the proletariat after his arrival in Paris) will only become stronger in the next political-philosophical itineraries. This is certainly the case of the path that leads from Marx to Kant.

\section{From Marx to Kant}

Here, without doubt, we can see an effort similar to the road that returns to Spinoza in order to flee from Hegel. In Lucio Colletti's work, for instance, at least before he would become a reactionary anti-Marxist, the reading of Kant served the purpose of opposing an antinomian logic to the dialectical logic of Hegel. Just as Althusser, in one of the most often-cited papers in For Marx, opposed the notion of contradiction with the concept of overdetermination imported from Freud's discourse, Colletti displaced the contradiction in favour of contrariety understood in relation to the Kantian antinomy. It was crucially important, in this sense, not to confuse - in the manner of the 'dialectics of matter' inherited from Hegel - the real oppositions with conceptual or logical oppositions. Thanks to the emphasis on an insuperable substratum of finitude, as Heidegger already had anticipated in his book Kant and the Problem of Metaphysics, therein supposedly consists Kant's advantage over Hegel, including for the comprehension of Marx. 'What we are dealing with in fact is oppositions which, precisely because they are real, are "devoid of contradiction" and hence have nothing to do with dialectical contradiction", Colletti explained. And he continued: 'Hence the old metaphysical commonplace (that still haunts the workers' movement) which holds that without dialectics there can be no struggle or movement, but only the inertia and immobility of death, is disproved once again. ${ }^{27}$ Kant, in this sense, serves once again the purpose of correcting the excesses of the Hegelian dialectic in Marx's thought. The return to Kant 
continues to be an immanent critique of Marxism, even as it raises the secondary question of knowing to what extent this interpretation prepared the way for Colletti in later years completely to abandon Marx and before his death to support the candidacy of Silvio Berlusconi.

On the other hand, in the approach especially to Kant's posthumous works that in the 1980s someone like Jean-François Lyotard began to propose after having participated for much of the 1950s and 1960s with Lefort and Cornelius Castoriadis in the heterodox Trotskyist project of the French journal Socialisme ou Barbarie, we can observe a highly self-critical attempt to step away from the metaphysical illusions in which the Marxist tradition would have remained trapped. If the project of Kant's critique can be defined as the clear delimitation of different families of phrases (cognitive, prescriptive, speculative, etc.) or different regimes of discourse (theoretico-scientific, ethico-moral, aesthetico-teleological, etc.), to use the updated nomenclature for which Lyotard finds inspiration in Wittgenstein, then the idea of the revolution appears as a kind of transcendental illusion in the technical sense of the expression. 'Revolutionary politics', Lyotard concludes, 'is based on a transcendental illusion in the political domain: it confuses what can be presented as an object for a cognitive phrase with what can be presented as an object for a speculative and/or ethical phrase; that is to say, it confuses schemata or examples with analoga. ${ }^{28}$ Thus, the return to Kant seems to have not only a critical but also a clinical function, enabling the analysis and curing of the illnesses that we caught from the young Marx.

\section{From Marx to Heidegger}

While sharing a few superficial features with the previous itineraries, the path that leads to Heidegger is very different, not only for the obvious reason that, as opposed to Marx's illustrious philosophical predecessors, it offers the advantage of a retrospective gaze, but also because this outlook turns out to be much more profound and encompassing in its destructive effects for the understanding of Marx than any path of return - with or without Marx, inside or outside of Marxism - to Machiavelli, Spinoza or Kant.

Here, indeed, we can no longer talk of an imminent reorientation. It is no longer a question, by way of a return to earlier sources, to recalibrate Marx's work by emphasising this or that forgotten 'aspect' or 'moment' to save him from his orthodox fixation into Marxism - or take drag him away from under the long shadow cast by Hegel's speculative dialectic. Rather, we are dealing with a paradigmatic itinerary that little by little, through multiple overlaps, anticipations and regressions, will end up removing us completely from the metaphysical 'grid' of which Marx, together with Nietzsche, would represent the culmination.

For a long time, perhaps this could not be said out loud, out of fear of being attacked as involuntary accomplices of the Right and treasonous enemies of the Left. But, according to thinkers such as Del Barco, the crisis of Marxism makes it possible to let go of the reins so that the criticisms to which it invites also may include all the humanist, productivist and otherwise still essentialist elements proper to Marxthat is to say, all those elements that we can only begin to destroy or deconstruct, perhaps, on the basis of a line of thinking such as Heidegger's. In this sense, the obligatory passage of so many contemporary thinkers - Oscar del Barco among them - via the multifaceted work of Heidegger, seems to open up a traumatic point of bifurcation: not just a mere displacement but a radical discontinuity with which a whole school of contemporary thought feels called upon, after the hangover of defeat, to overcome the tradition of Marxism with which until then they had kept up at best an oblique debate and at worst a complete misunderstanding.

\section{Neither itinerary nor paradigm: Heidegger's turn}

Before tracing some of the stages in the paradigmatic itinerary from Marx to Heidegger in the case of Oscar del Barco, however, we should at least acknowledge that to the trained ear of this Argentine philosopher this very expression will sound as a gross simplification, since the genuine thinking of being according to him offers strictly speaking neither an itinerary nor a paradigm. Both denominations would be misguided: the first because, as a methodic path, an itinerary would presuppose a place of origin and a final destiny; and the second, because the critique never reaches nor pretends to reach the systematicity of a scientific paradigm, which would presuppose a still all-too-technical outlook on knowledge like the one that is being thrown into doubt together with the teleology of history on the necessary road towards progress or the revolution. 
'Paths, not works' (Wege, nicht Werke) is the lemma that Heidegger himself proposed for the publication of his complete works. But for Del Barco, if there are no works, there also are no paths, not even the ones that lead nowhere, like the 'hollow roads' or Holzwege of the German thinker. Thus, we can read in El abandono de las palabras:

Every road presupposes a point of departure and a point of arrival, and even in following 'paths' one follows an itinerary, that is, one is guided by a telos, albeit a phantasmatic one. In the spirit not only are there no roads but fundamentally there is not a someone who, should they exist, would follow them. What is there is what is here-now in the nontime and the nonplace. Every path, every method is always charged with the violence of Reason exerting itself against nature as much as against the human being: never can a method receive the unknown in its coming to light. The thinking-without-reason, on the contrary, without either paths or works, lives in the poverty of what is not, that is, in the intensity of the illumination released from things, attentive only to the awaiting of grace of what there is. ${ }^{29}$

If Marx and Nietzsche, in spite of Heidegger's take on them as still (though perhaps the last) metaphysical thinkers, serve the purposes of the Argentine philosopher in order to abandon himself to the grace of what is, this is because they break open the paradigms of technical-scientific knowledge to its unknown side, the constitutive other without which it is impossible to think the system as a whole.

Marx fantasised about the whole. 'He wishes to have the whole before his eyes, as he told Engels when full of optimism he described to him the particularity of his "method"; but the whole was his phantasy; the ultimate phantasy of the logos, of course', Del Barco observes. 'Only beyond the whole did the other begin that turned the whole into a fragment by converting the whole in the true capitalist "dream of reason". ${ }^{30}$ If the dream of reason produces monsters in the case of really existing socialism no less than under capitalism, as Del Barco has not stopped arguing with Goya's words, from the publication of his Esbozo de una crítica a la teoría y práctica leninistas onward, then the critique of this dream cannot speak in the language of a paradigm shift, because the intensity of the new thinking, like that of life itself, does not fit the mould of theoretical and economic parameters typical of modern metaphysics:

On this point Marx and Nietzsche intersected: the latter by dismantling the functioning of metaphysics at a theoretical level (keeping in mind that the theoretical is since always a mirage of the System); the former by realizing a similar analysis in the order of the economic structure (the 'economic' too is a mirage) of the capitalist system. Both produced consternation in their respective scientific communities of economists and philologists, who had to confront works that were atypical for the standards in use, with theoretical itineraries that moved freely in the cultural web of the time by bringing to light a complex network of structures of power ignored by 'science' until then. ${ }^{31}$

Finally, if Marx as well as Nietzsche promises an overcoming or an escape from the framework of metaphysics, as Del Barco suggests, at least in a first stage, when he compares the former's dream of 'communism' with the latter's 'overman' or 'trans-human', we also cannot reduce this rescue operation or salvation to a set of purely theoretical statements. Notwithstanding the impression created by a superficial reading of the 'Theses on Feuerbach', it is not even a question of putting into practice a prior theory, but of a complete overhaul of all the habitual relations between theory and practice. This is why Del Barco writes:

Both Marx and Nietzsche proposed a rescue of sorts: for the first it depended on the development of the negative forces immanent in the social, which due to their position in the general framework of the capitalist dialectic necessarily had to aim at a world without dominant hierarchies in which the center would be the human being turned into free-being; for the second it depended on the assumption on the part of a trans-human of the intensities of the eternal return of the same (the trans-human is the human being who assumes intensity). Beyond the purely cognitive impulse both were driven by the pathos of the transvaluation of all values. This was the mark they left, the one that separated them from the academic order and projected them toward an unprecedented spatiality for theory as much as for practice, and producing a rupture of such magnitude that it cannot be apprehended either with the concept of 'paradigm' (common today in the scientific order) or with the devalued concept of 
'revolution': rather, we would have to think of the moment, as William Burroughs says, when the fish got out of the water and onto the land. What should we call this? What becomes visible today on the theoretical stage? ${ }^{32}$

Del Barco will not immediately answer this last question. But if already in Marx or Nietzsche it is impossible to speak of a 'paradigm', with all the more reason would we be giving proof only of stubbornness if we presented as 'paradigmatic' the itinerary from Marx to Heidegger. Del Barco's books are always collections of essays, with texts whose first date of publication can sometimes be separated by several years from the last, so that the latest texts included in El otro Marx almost coincide, chronologically speaking, with the earliest ones included in El abandono de las palabras, even though there is a whole decade between both books. Within each collection there are considerable tensions and variations among the proposed ideas. Nonetheless, no matter how irregular the spatiality of the path may be, full of gaps, inclines and superimpositions, what should be clear is that at the end of this trajectory it also will not be possible any longer to speak of 'revolution' or 'revolutionary practice', but after Heidegger's turn it only will be an issue of 'being' or 'letting-be', following the word of the poets.

As in El otro Marx, Del Barco will persist all along his politico-philosophical itinerary in the quest for the other side of the whole, but he will no longer pretend to answer the question 'What is to be done?' except with the paradox of a doing that is a non-doing. 'Even though it is true, on the one hand, that nothing can be done that might point to the total destruction of the System, it is also true that, on the other hand, it is possible to do the non-doing of the real non-system', he will write in 'El "peligro" y lo que salva', included in El abandono de las palabras.

What is more: the event cannot transform the System at once and totally into something different, but at the same time it can happen only in the human being, which means that only in this human being, without any possible type of visibility, does the other of the System begin. ${ }^{33}$

The other is not something that human beings can produce, enact or work out; at most they can let this uncanny dimension of being come to them.

\section{Crisis and release: from militancy to abandonment}

Since we are not dealing with an itinerary in the technical sense, it will be necessary to avoid the use of terms such as 'stages' or 'moments', which would give the mistaken impression of a linear development, whether dialectical or not. It will be preferable to speak of 'stances' or 'instances', insofar as we are dealing with different postures or forms of being in the world. Even though they are referred to with the proper names of two or three philosophers (Marx, Nietzsche, Heidegger) with their different ways of relating to one another, in fact what these names signal are ways of carrying oneself or standing in the midst of the distress. And in Del Barco's thinking, as I mentioned earlier, several of these modes can find themselves in tension or opposition between the covers of one book or even within a single essay.

In any case, we must begin by recalling how Heidegger himself, in his 'Letter on "Humanism"' to the French philosopher Jean Beaufret immediately after the Second World War opened the possibility of a 'fruitful dialogue' with Marx:

What Marx recognized in an essential and significant sense, though derived from Hegel, as the estrangement of the human being has its roots in the homelessness of the modern human beings. This homelessness is specifically evoked from the destiny of being in the form of metaphysics, and through metaphysics is simultaneously entrenched and covered up as such. Because Marx by experiencing estrangement attains an essential dimension of history, the Marxist view of history is superior to that of other historical accounts. But since neither Husserl nor - so far as I have seen till now - Sartre recognizes the essential importance of the historical in being, neither phenomenology nor existentialism enters that dimension within which a productive dialogue with Marxism first becomes possible. ${ }^{34}$

In spite of its coming close to the root of the question of the being of history, however, Marxism finally could not stave off the dominance of a still metaphysical conception of productive human labour. According to Heidegger, Marx by having put the Hegelian dialectic back on its feet, just like Nietzsche by inverting Plato, would still have remained within the closure of metaphysics, albeit as their last representatives: 
Absolute metaphysics, with its Marxian and Nietzschean inversions, belongs to the history of the truth of being. Whatever stems from it cannot be countered or even cast aside by refutations. It can only be taken up in such a way that its truth is more primordially sheltered in being itself and removed from the domain of mere human opinion. ${ }^{35}$

From the more primordial vantage point of Heidegger's thinking, in other words, Marx still partakes of the concealment or oblivion of being. This is the interpretation with which, in a first stance, Del Barco's work will try to measure itself.

\section{Marx with Nietzsche against Heidegger}

In various essays in El otro Marx the Argentine philosopher argues against Heidegger's reading of Marx and Nietzsche as the final fulfilment and completion of the oblivion of being. In his 'Letter on "Humanism"' Heidegger had said that, to achieve that 'fruitful dialogue' he envisioned possible with Marxism, it was necessary 'to free oneself from naïve notions about materialism, as well as from the cheap refutations that are supposed to counter it'. He continued:

The essence of materialism does not consist in the assertion that everything is simply matter but rather in a metaphysical determination according to which every being appears as the material of labor. The modern metaphysical essence of labor is anticipated in Hegel's Phenomenology of Spirit as the self-establishing process of unconditioned production, which is the objectification of the actual through the human being, experienced as subjectivity. ${ }^{36}$

But the same objection could be raised against the author of Thus Spoke Zarathustra. Nietzsche's inversion of Platonism, too, would mark only an - extreme - inversion of the metaphysics of subjectivity. As Del Barco indicates, referring to Heidegger's lectures and treatises on Nietzsche: 'His central thesis holds that Nietzsche represents the culmination of nihilism, as well as the culmination of metaphysics,' in the extent to which Nietzsche still thinks of the overman in terms of subjectivity, even as he inverts the Platonic-Christian evaluation of the human being as slave to resentment.

What Nietzsche would not have realized is that his inversion of metaphysics carries metaphysics with it: the inversion of metaphysics does not overcome metaphysics; rather, in a bewildered way it proposes another metaphysics: with the aggravating circumstance that the new metaphysics appears as nonmetaphysical in the very same movement in which it brings metaphysics to its culmination. ${ }^{37}$

Del Barco, in a first original approximation to this debate, seeks to rescue both Marx and Nietzsche from the severe judgement on the part of Heidegger. About the author of Capital, for example, he points out in the essay 'Hacia el otro Marx':

The concealment of being manifests itself as technology; if one asks: What is the concealment of being? one necessarily must signal technology. But, and this is something that Heidegger did not see, obsessed as he was with the constitutive aspect of Marxism, Marx's entire theoretical work is an immense phenomenology-critique of technology turned into social subject and of the world of human beings turned into the world of fetishes that remove them as much from the object as from the other and from themselves, fetishizing themselves in function of an objectivity that takes away being invested as subject, which flows by converting the real social subjects, whether capitalists or workers, into 'personifications' in one case and 'bearers' in the other. Behind the 'things' Marx sees the social relations that constitute them: a world of objects flowing without human beings, such as the frame whose mechanism Marx tries to decipher throughout his entire life by signaling the moments of condensation, concealment and mimesis, as well as the 'gaps', which are not only theoretical, and the death that conforms the immanence of the system. In short, it is a cartography destined for war and not for knowledge for knowledge's sake. One may like it or not, but this is how it is; except if we incorporate Marx in the order of the university, and make him into a pure object of promotion and a 'method' that founds 'disinterested' forms of knowledge. ${ }^{38}$ 
Similarly, in an essay taken up in El abandono de las palabras, Del Barco defends Marx against Beaufret and Heidegger. It is not true, he claims, that Marx would have proposed a humanist-productivist definition of 'man' on the basis of his purely technological relation to the world, mediated by labour:

Marx radically criticized the idea of man understood as substantial subject, whence his utilization of the term 'man' must be seen from a point of view that is ulterior to the critique and situated correctly in its context of signification. In other words: the critique does not impede the use of the terms, either in Marx or in Heidegger; rather, it demands a certain spirit of subtlety in its use. ${ }^{39}$

What is more, in one instance the Argentine thinker goes so far as to suggest that the idea of 'communism' for Marx, about which Heidegger in his 'Letter on "Humanism"' had said that it could not be distinguished essentially from 'Americanism' if it was understood only in its technologico-metaphysical sense ('Whoever takes communism only as a "party" or a "Weltanschauung" is thinking too shallowly, just as those who by the term "Americanism" mean, and mean derogatorily, nothing more than a particular lifestyle $\left.{ }^{\prime 40}\right)$, could be read more subtly as the facilitation of the 'realm of freedom' as the region of 'the open', in a sense close to the thinking of the truth of being as unconcealment in Heidegger. 'For Marxism it is a question of installing the open as real and not only theoretical possibility by way of the institution of an absolutely open society such as communist society,' Del Barco wrote in El otro Marx. And, as if to complete the provocation, he added: 'What keeps us from interpreting this as the facilitation of aletheia?'41

Going even further in his polemical confrontation with Heidegger's interpretation, Del Barco in this sense establishes an analogy or isomorphism between Marx's 'communism' and Nietzsche's 'overman':

Here too it is possible to signal a close isomorphism with the famous 'inversion' of Platonism that Nietzsche carries out: this must not be understood as the inverted maintenance of the same terms playing at metamorphosis in the order of the pure-ideal, in which case what would be maintained would be the global field in which the inversion is produced so that the real, by remaining untouched, would end up being consolidated. Here what is at issue is the questioning of the real by delegation: it is the real itself that clears the inversion. This is why Nietzsche invented the term 'overman' and Marx the term 'communism': the point is an outside of the inversion. Not to see this and stay at the level of the inversion as mere ideality means to deprive oneself of this entry into the subversive order for both thinkers as clearing - toward a beyond of the theoretical, which initiates an errancy without-totality, that is to say, a transmetaphysical wandering. The insistence of this theme is determined by the force that does not belong to Marx and points in the direction of a type of non-subjective equality as the condition for the social unfolding of intensities. ${ }^{42}$

Both Marx and Nietzsche, in other words, would signal a social unfolding of intensities without dominance, based on a mysterious type of equality that would be non-subjective, because it would not be submitted to the modern-humanist principle of individuation. They would offer two 'alternatives of the posthuman', to use an expression that serves as the title for a recent anthology of Del Barco's writings:

Here we must distinguish between the non-humanism of the System and the non-humanism of the beyond of the human. The first implies its machinic annihilation, whereas the second implies its overflow without limits. It is in the difference between these two alternatives of the posthuman that the issue is a historical epoch that will have to choose ever more clearly between the truth of freedom and the fetishism of technological-productivist violence. The importance that Marx and Nietzsche have for us today, beyond the outdated nature of some of their individual statements, is due to the way in which they marked the significance of these alternatives: it was on their basis that the critique of metaphysics was put into motion, understood in its most profound sense as the grid of real and ideal forms of scission. ${ }^{43}$

It is possible, though, that Nietzsche holds some advantage in this regard over Marx. Both, at bottom, were looking for an order that would not be split and they showed to what extent the really existing order - capitalism for one, Platonic-Christian morality for the other - was still tributary to metaphysics: 
In other words: Marx showed that the economic structure is metaphysical, displacing the philosophical statement in the direction of a praxis whose teleology he announced as a 'reign' of free and equal beings. From another perspective, Nietzsche too devoted himself to dismantling metaphysics, proposing an ethical alternative that entailed the need to break with the closure of 'individuation' so as to enter the world of the Dionysian. ${ }^{44}$

However, because of his impulse to derive his critique of capitalism scientifically from the socio-economic conditions of the process of production, the author of Capital perhaps would not have reached the same extreme point in the dissolution of the principle of individuation as the prophet of Thus Spoke Zarathustra:

In this sense the concept of socio-economic formation, which fulfilled in a complex but schematic manner his theoretical interest, kept Marx from envisioning principles that might go beyond the hypergeneral 'reign of freedom', and in this way he abandoned to the dominant ethics of his time the conduct of what he called the 'revolutionary class': the idealist concepts of the class in-itself and for-itself were insufficient to fill the void of theory in its relation to the real life of historical 'subjects'. By contrast, Nietzsche was able to constitute to exemplary and concrete figure of the beyond-of-the-human, as a spatiality inherent in the overcoming of the 'principle of individuation', insofar as he based it not only on historically consistent models but also on the experience that he himself lived through of the eternal return of the same. ${ }^{45}$

On the basis of this critical note, it is possible to discern a second stance or instance in Del Barco's approach to the debate between Marx and Heidegger.

\section{Marx with Heidegger against 'Marxism'}

Part of Marx's legacy, according to this argument, suffered the effects of a metaphysical fixation called 'Marxism', from which only a deconstruction will be able to liberate us. In this deconstruction, Marx with regard to labour can be as radical as Sade with regard to sexuality; and against capitalism as necessary as Heidegger against technology. But if it is a matter of drawing the necessary conclusions from this confrontation for the world of politics, we will have to see if the concept of 'politics' should not rather be subjected to an emptying of its militant character in the name of an 'impolitical' turn in the very definition of the political, as around this same time a number of Italian philosophers such as Massimo Cacciari and Roberto Esposito began to suggest.

Something within Marxism, in other words, begins to tear apart at the seams. There is a scission within the search for an order that would not be split. A distance opens up that perhaps cannot be bridged between Marx and 'Marxism' (in scare quotes), which corresponds to the metaphysical fixation of 'the thought-of-Marx', as we can read in El otro Marx:

The example is Marx and the tornness in which he finds himself. Such a tornness speaks to his other side. It is necessary to mark its intensity, 'use it', so that the fissures may come to light and they too abandon the simulacrum of unity. The Marxist 'ideology' concealed precisely this drama and what consequently was 'embodied in the masses' was the parody of a thought: what was repeated was the split matrix of a despotic social order on course to becoming dominant at a planetary level. The parody is made up of a void and a concealment; the void is shown with royal emblems; what is concealed is the need, the tragedy. In the final instance what became common sense were the old formulae of metaphysics introduced by force or ruse into the empty shell of a phantasmatic 'Marx thought' that thus was transmitted in 'Marxism'. ${ }^{46}$

In his introduction to the collection of essays El abandono de las palabras, Del Barco will refine his reading of this 'transmission' by picking up on Heidegger's indications in his 'Letter on "Humanism"' and applying them not only to the handbook versions of 'Marxism' but also to Marx himself. The fact is that there is something in the critique of the political economy of capitalism in Marx that still leaves in suspense the question about technology.

It was Marx who, on the basis of the 'normal science' of his time, analyzed the process of the constitution of abstract labor and of the ideological order in which it is expressed at a theoretical level. However, he left in suspense the question regarding the prior opening of the possibility that at the heart of the social made this separation feasible. ${ }^{47}$ 
To speak of practice and theory, or even their union into revolutionary practice or praxis according to the third of Marx's 'Theses on Feuerbach' ('The coincidence of the changing of circumstances and of human activity or self-change can be conceived and rationally understood only as revolutionary practice') does not yet mean asking the previous question about the role of technology, in the sense of technè for the ancient Greeks (Plato and Aristotle) in the opening of a difference between nature and human that subsequently would be reformulated, with or without harmonious synthesis, as the critical or dialectical duality between res extensa and res cogitans (Descartes), between the thing-in-itself and the 'I think' (Kant) or between the in-itself and the for-itself (Hegel). In this sense, to use Heidegger's words in the 'Letter on "Humanism"', Marx did not separate himself enough from the technical or technicist interpretation of the history of being:

In order to learn how to experience the aforementioned essence of thinking purely, and that means at the same time to carry it through, we must free ourselves from the technical interpretation of thinking. The beginnings of that interpretation reach back to Plato and Aristotle. They take thinking itself to be a technè, a process of deliberation in service to doing and making. But here deliberation is already seen from the perspective of praxis and poièsis. For this reason thinking, when taken for itself, is not 'practical'. The characterization of thinking as theoria and the determination of knowing as 'theoretical' comportment occur already within the 'technical' interpretation of thinking. Such characterization is a reactive attempt to rescue thinking and preserve its autonomy over against acting and doing. ${ }^{48}$

Now, as Del Barco observes, only a 'destruction' or 'deconstruction' of the history of being will be able to free us from the technical-metaphysical interpretation of the relation between theory and practice in Marx:

One of the central themes of Heidegger after the "turn" is that of the essence of technology; it is around this theme that his thought about the crisis is articulated and at least one aspect of what might be considered its relationship to Marxism, whose importance was made clear in his 'Letter' to Jean Beaufret. ${ }^{49}$

This continues to be ignored, according to Del Barco, whenever politics is reduced to its militant partisan concept: 'The political parties, ever more dominated by social engineering and professionalism, both the subsidiary products of technology, ignore the problems that contemporary philosophy brings out with regard to technology as formative of the world, as nihilism, and as epoch of the culmination of metaphysics. ${ }^{50}$

Distancing himself both from orthodox 'Marxism' and from an all-too-technical concept of revolutionary politics as 'praxis', Del Barco will trace a much more profound transformation in the very concept of the political, which has entered into a crisis that is no longer limited to Marxism alone. In order to capture this transformation, which is the principal motivation behind the change of perspective from Marx to Heidegger, we must turn our gaze to movements that are not strictly political or philosophical but mystical and artistic:

The ones who noticed with greater clarity these transformations of everyday life and their theoretical paradigms, summed up in the so-called crisis of politics, were certain aesthetico-religious movements that in a significant way constituted themselves into the expression of a set of ideas and practices the central objective of which was the destitution of the subject as the ultimate foundation of metaphysics understood as structure of the technological system. These movements, beyond the anomalies and normalities of a society that is absolutely reified, initiated the abandonment of the historico-political scaffolding that undergirds the order of the different instances that make up the social. It is an act of falling that transcends the theoretical self-consciousness that it has of itself, because it belongs more to the knowledge of the body, to the order of art and mysticism, than to the scientific and even philosophical rationality. And it is especially on the basis of this point of tornness, of the event of un-being that characterizes the other side of domination, that we can observe the essence of the teleology of the System as it gestures toward the a-signifying element as the culmination of the form of technology. ${ }^{51}$ 
Heidegger's magnetic force of attraction on this point is so powerful and inclusive that it leaves nothing outside of its orbit. One could certainly ask if the Marxist critique of capitalism should not be extended to a critique of the technological manipulation of the world, based on the 'destruction' of the history of being. But from the moment one adopts this frame of thought in the thinking of being, any other reading - whether social, economic, ideological, political, cultural, and so on - by definition will fall short. It would be, in Heidegger's terms, a vulgar 'ontic' interpretation that, like all perspectives based on being as mere entity, finds itself necessarily pre-inscribed within the millenarian horizon of Western metaphysics. From this follows the seemingly irrefutable gesture of 'destruction' or 'deconstruction': any refutation would mean relapsing back in that which is being questioned in the only thinking worthy of its name, that is, the poetic thinking of being.

In an essay included in La intemperie sin fin, taking advantage of a comment on Diego Tatián's book on the politics of Heidegger and his Nazi compromise, Del Barco concludes with a series of formulations that could sum up his entire later trajectory:

Can we speak of a 'politics' and of an 'ethics', of a politics without politics and an ethics without ethics, on the basis of Heidegger's thinking? Or are 'politics' and 'ethics' words whose metaphysical investment turns out to be impossible to disentangle from them? In our hermeneutic perspective it would be more convenient to forget about words, to abandon them, to allow the event, the gift, and to let being be absolutely. Every must imposed as legality, like every teleology imposed as order, and every theology and teleology imposed as Meaning, make it so that the manifestation of the donation becomes predetermined by means of the imposition of the schemes of metaphysical humanism. We therefore find ourselves confronted with a turn (Kehre) that must not be considered as a mere rotation in the problematic but as a critico-theoretical destruction of the metaphysical structures themselves as technical order and culmination of nihilism. ${ }^{52}$

What is left, then, of that 'fruitful dialogue' of Heidegger with Marx? Today, apparently, very little or nothing:

This was a project without outcome and today it would seem that the possibility of a dialogue is closed by the dramatic acceleration of the worldwide process of fetishization as the unfolding of nihilism and technology. Those that previously could be fields for an encounter in the realm of thinking nowadays are drowned out amidst the force of the unfolding of the technological age and the prospects of 'salvation' no longer pass through any type of political activism in the exact degree to which capitalist and 'socialist' countries have become unified in the same productivist teleology in which the libertarian aspiration was subsumed almost entirely under the project of material well-being without spirituality. And since the Heideggerian God takes time to appear the world has entered a zone of decline: 'that which saves' no longer is the old millenarian project of the 'reign of freedom' nor the self-consciousness of the 'essence of technology': and thus thought must decline, at the margins, in the dispersion, toward the world of poetry. ${ }^{53}$

Here, in a third and final instance, the possibility opens up for a mode of holding oneself in the midst of the distress that can no longer be qualified as political but rather, perhaps, as an impolitical comportment or, better yet, a poetic mode of being: an instance or stance as a state of being or un-being.

\section{Heidegger with Heidegger}

From this point onward everything turns circularly around Heidegger. And the different figures of the 'turn' repeatedly proclaimed by the German thinker himself (the famous Kehre or 'reversal' from Being and Time to 'On Time and Being', from the existential analytic to the history of being, from resolution to abandonment, from decision to the pure 'there is', and so on) run across the entire terrain of a mystico-poetic thinking in which there is no more space for militant revolutionary acting or doing. No more revolutionary praxis or productive work but the pure inoperativity of a non-doing without will or dominion. Confirming after all Heidegger's original judgement in his 'Letter on "Humanism"', both Marx and Marxism in this instance call squarely within the epochal regime of technology and the will to power 
as the will to will in which no 'must-be' will save us except, perhaps, in an attitude of patient waiting and the opening onto the coming of the last God.

To understand how Del Barco's thought presents itself in this final instance, we can refer to some of the key terms that he himself enumerates, almost all of them inspired by the thinking of the late Heidegger:
Here, as an intimation in the sense of the final Heidegger, that is to say, of his properly ethical moment, we can make room for the words letting-be, releasement, abandonment, desistance, and diffidence. But can these words constitute the modality of an ethics? In an epoch characterized by doing, in which the dominion of nature and human beings is the concept of all concepts (and the dominion is essentially the metaphysical), in which politics as form of power constitutes the human activity par excellence, what possible meaning can we ascribe to the letting-be, the self-withholding and the delinking in order to let being be? What can be the meaning of a world without causality or finality? In an epoch in which political praxis appropriates for itself the meaning of the human as well as the hopes for 'salvation', what can be the ethical meaning of letting? ${ }^{54}$

It is clear that the meaning of letting cannot be political, if by this we continue to mean a technical domination over against the world of humans and things. For if technology is understood from the more originary point of view of the history of being, any practical activity of the human being appears as an integral part of the coming into being of metaphysics:

\begin{abstract}
Above all we should remember that for Heidegger the planetary epoch of technology is an epoch of being and not a simple human construction: it is the epoch of the culmination of metaphysics in the form of technology as the 'essence of technology'. From this perspective everything the human being does with an eye on generality falls under the heading of technology (we might say that we are dealing with something similar to the Hegelian 'ruse of reason' metamorphosized into the ruse of technical reason: here even what is opposed to it is part of its dynamic). From this follows the 'crisis' of the political order, which always, in the modern epoch, implied an adherence to the legitimacy of technology and the acceptance of the game of the System that exerts its power in the guise of a conjunction of alienation and representation. ${ }^{5}$
\end{abstract}

If we do not want to lose sight of the fundamentally a-topian essence of politics, already remarked upon in El otro Marx, Del Barco in El abandono de las palabras proposes the hypothesis that perhaps we must consider non-doing as a more originary state than any practical action subjected to the ethico-political norm of a must-be. Such is the extent of the plight of distress in which we find ourselves that not even politics can be trusted:

The magnitude of the disenchantment questions the classical order of politics insofar as it is a pre-constituted sphere that is already hierarchized for a pluriform and anarchic practice that is constrained into a unilinear order. On the grounds of this situation, is it not possible also to think of nondoing as belonging paradoxically to the dominion of technology? Let us venture to say the following: nondoing can be considered a distinct type of doing, of doing as 'spontaneous action without the search for a result', of the doing 'without why' and 'without what for' of the poet Angelus Silesius, of a 'state-of-nothingness' that summons up a waiting or awaiting of being that does not fix beforehand the form of its advent. A waiting without any must-be to which it should conform. ${ }^{56}$

The least inappropriate words to speak of this awaiting of being tend to be found in the language of the poets. But it is not the expression of a truth that would depend on them, since it is not the subjectivity of the poet but language that speaks through the poets, in an experience closer to a mystical state than to a logico-linguistic statement:

In its turn this alternative can be stated by saying that it is a question of a saying-of-silence, of a letting silence speak with a speech that is proper to silence, because this silence is the speech. Ontologically transcending the someone, be it called ego, soul, or man, as subject 
of language, silence is what speaks and what is spoken in the speaking. The speech is of the silence that interrupts as speech in the no-one, in this purely apophatic element in the sense of the indeterminability of negative theology. In this case the someone is destituted (at its own level) while thus enabling the saying-of-silence. In the place of a subject that speaks about the silence there is the silence that speaks in the place of the disappearance of the subject and as disappearance of the subject. ${ }^{57}$

Instead of a doing, a non-doing; instead of the speech of communication, the silence of speech; instead of the human, an intensity; instead of practice, abandonment; and instead of the revolution, the waiting for an event without event. Though it would still be abusive, as we recall, to speak of a point of arrival, it nonetheless seems that we have come to the end of the road. It was not a goal, because it was never a question of subordinating life to the value of a why or a what for. But we do find ourselves in a new state, a different stance or another way of standing: another form of being in the world. And here, in this abandonment, it is possible one last time to hear the call of the other that returns time and again in the margins of Del Barco's path of thinking:

The System annuls the other but the other is always reborn and different: it is a hole where the full presence of the System is captured as nonsense. The other is a-morphous, a-theoretical, a-religious, a-political, a-moral. Its investment is non-doing, non-being. Always at the limits of the indefection and the ineffable. The other is the 'danger' for the system, that is to say, the real possibility of dissolving its alienation. ${ }^{58}$

The crisis is no longer limited to the crisis of Marxism. Now the crisis is nothing less than epochal, civilisational, planetary. In such a context, even Heidegger remains silent before the question 'What is to be done?' But perhaps in this silence there is safeguarded the promise of a life that would no longer be subjected, a life without voluntary servitude:

The planet has ceased to be the homeland of humanity and more so than of a crisis it is a question of the culmination of the essence of metaphysics in the form of technology and nihilism. Heidegger keeps silent when he is asked 'What to do?' It would seem that his silence means a non-doing charged with mystical connotations. To think; thinking-thought; to render thoughtful; thinking-poetry. The clearing in the forest; the pathmarks; paths that lead nowhere; the 'without why and without what for' of Angelus Silesius. ${ }^{59}$

It is not possible to go any further. To suppose a beyond would only serve the purpose of subordinating life once more to the norm of a why or a what for. There is no theoretical or philosophical alternative that might lift us out of metaphysics, because there is nothing more metaphysical than the desire to overcome metaphysics:

It follows that there is no feasible 'philosophical' alternative that might have confidence in technology as a possible and future 'salvation' of the human being. At this crossroads is where the meaning of letting-be shines forth. Letting be means non-doing, but by no means should letting-be and non-doing be understood in the vulgar sense as nihilism and conformism. Rather, we must think that this is where the System fails, whether it turns out to be impossible to completely suppress the others without suppressing itself or because in the other there is something that cannot be suppressed. In this impossibility, in this final remainder, is where some day, perhaps, the salvation may come up that Hölderlin's song was longing for. ${ }^{60}$

Following Heidegger's example, Del Barco thus turns to the language of poetry as the privileged site where the other of technological nihilism might speak in the midst of a predominant silence or quietude.

\section{Epilogue}

The outcome of this trajectory from Marx to Heidegger may seem to be rather melancholic: to look for the sought-after salvation in the danger itself, in the failure or impossibility of the system, including with the wager on the immediate reversibility between the failure and the salvation. Collapsing the distance between the system and its accursed share of otherness, our only hope, if it is not the pure passivity 
of melancholy, seems to reside in the mystical or messianic hope in a strict coincidence between the two poles. Whence the appeal not only of the Rhineland mystics such as Meister Eckhart but also of figures such as Angelus Silesius, Blaise Pascal, the final Schelling or the Wittgenstein who speaks of the 'mystical element' in his Tractatus Logico-Philosophicus. Del Barco shares some of these preferences with Derrida. In Force of Law, for instance, the latter writes: 'Discourse here meets it limit - in itself, in its very performative power. It is what I propose to call here the mystical. There is a silence walled up in the violent structure of the founding act; walled up, walled in because this silence is not exterior to language. Here is the sense in which I would be tempted to interpret, beyond simple commentary, what Montaigne and Pascal call the mystical foundation of authority', and almost immediately afterwards the French philosopher adds: 'I would therefore take the use of the word mystical in a sense that I would venture to call rather Wittgensteinian. ${ }^{61}$

Nonetheless, it is also curious to see how the wager on the mystical reversibility - showable but not sayable in Wittgenstein's terms - between discourse and its limit, between Western reason and its other, or between the system and its accursed share, carries echoes of an argument that often has been seen as one of the principal defects of Marx's discourse, if not of all of Marxism inspired by it. I mean the argument according to which the communist revolution is necessarily the moment when those who have nothing to lose but their chains will be all in a future society without classes. Thus, in his 'Introduction' to the Critique of Hegel's 'Philosophy of Right' from 1843, in which the formal argument about the proletariat as revolutionary subject first makes its appearance, Marx announces the imminent reversibility of the total loss and the total recuperation of the human essence. This is because for the young Marx the positive and not merely critical possibility of human emancipation depends on 'a sphere, finally, that cannot emancipate itself without emancipating itself from all other spheres of society, thereby emancipating them; a sphere, in short, that is the complete loss of man and can only redeem itself through the total redemption of humanity'. ${ }^{62}$

Thus, we obtain the following conclusion in the case of Heidegger (via Hölderlin): there where the danger lies, there also lies the salvation; and in the case of Marx (via Hegel): the total loss or alienation will be at the same time the place of the total redemption. In both cases, it would seem as though we are confronted with an identical argument, at least formally speaking. Only a little push would be needed for absolute negativity to turn over into absolute positivity. There is, however, a crucial difference between the Heideggerian tradition and the Marxist orientation. This is because for Marx the reasons for why the proletariat acquires a revolutionary function are historical and material, whereas in Heidegger's thinking, as well as for his most agile readers in France, Italy or Latin America, these reasons seem much rather to depend on an act of faith in the impossibility that would be constitutive of the system itself. In other words, if it is impossible to square the circle of reason, if its system is constitutively incomplete and finite, or if there is always a remainder of chance, contingency and undecidability, for the Marxist tradition this is due to the fact that the capitalist system is based on elements that the system itself cannot produce or commodify entirely, that is, above all, land and labour, whereas in the Heideggerian tradition and its Derridean radicalisation the arguments tend to be structural, quasi- or ultra-transcendental, to account for the difference, dislocation or incompleteness inherent in the whole system of signification.

Here, in sum, we do well to return to a basic premise of Oscar del Barco's El otro Marx, which is the notion that the concept is always the form of the real. This may sound overly Hegelian, as if to affirm that the real is the rational. But in an updated reading of Marx this famous or infamous affirmation of Hegel's philosophy of history does not serve to justify everything that is real in the name of reason but, on the contrary, it serves to make reason dependent on the real. In this way, even the notion of absolute knowing in the speculative idealist dialectic, but also the philosophies of difference that are so giddily opposed to it in the French or Italian tradition, can and must be read in a material key, starting from the dregs of the concept as so many forms of the real. No doubt, this is something that Del Barco no longer does after his turn to Heidegger, Eckhart, Schelling or Wittgenstein, but it is a path backward that can be opened up on the basis of his own proposals about the 'other' Marx - the Marx of 'the other side' of the concept. And from there to return from philosophy to the history of capitalism as real abstraction.

\section{Notes}

${ }^{1}$ Althusser, 'The crisis of Marxism', 215.

${ }^{2}$ Althusser, 'The crisis of Marxism', 216. 
${ }^{3}$ Althusser, 'The crisis of Marxism', 219. Althusser's theses immediately provoked a torrent of replies, attacks and counter-arguments. He himself responded a few months after the Venice conference to a new invitation from Rossana Rossanda with another text for the collective II Manifesto, 'Marxism as finite theory', which would be included in Spanish translation as 'El marxismo como teoría "finita"', together with a long chain of responses in a volume published in Mexico and Argentina in the series 'El tiempo de la política'; see Althusser, 'El marxismo como teoría "finita"', in Discutir el Estado.

${ }^{4}$ I quote from the recent re-edition but occasionally make corrections based on the first edition: Oscar del Barco, 'Hacia el otro Marx', in El otro Marx, 25. For a broader interpretation of this book, see Bosteels, 'El otro Marx: Filosofía y teoría crítica', 39-68. Unless otherwise noted, all translations are my own.

${ }^{5}$ Del Barco, 'Hacia el otro Marx', in El otro Marx, 22.

${ }^{6}$ Del Barco, 'Entre Marx y Hegel', in El otro Marx, 89.

${ }^{7}$ Del Barco, 'Althusser en su encrucijada', in El otro Marx, 113-4, n. 2.

${ }^{8}$ Del Barco, 'Observaciones', 12-13.

${ }^{9}$ Del Barco, 'Observaciones', 12.

${ }^{10}$ See especially Marx, Critique.

${ }^{11}$ Del Barco, 'Sobre el problema', in El otro Marx, 61.

${ }^{12}$ Del Barco, 'Sobre el problema', in El otro Marx, 61-2. Here the original formulation in the first edition appears to be more correct than the recent re-edition.

${ }^{13}$ Del Barco, 'Hacia el otro Marx', in El otro Marx, 32-3.

${ }^{14}$ Del Barco, 'Sobre el problema', in El otro Marx, 44-5.

${ }^{15}$ Nancy, 'The forgetting of philosophy', in The Gravity of Thought, 54 (translation corrected to restore the name of Webern the composer, not Weber the sociologist).

${ }^{16}$ Nancy, 'The forgetting of philosophy', 53-4 (translation modified). Nancy subsequently would revisit his interpretation of May ' 68 ' at regular intervals, for example in 1998 in the essay 'Changement de monde', included in Nancy, La pensée dérobée, 139-48; and then again another ten years later in Nancy, The Truth of Democracy.

${ }^{17}$ Del Barco, Esencia y apariencia, 102. This text can also be consulted in the anthology of Del Barco, Escrituras: filosofía, 92, n. 42.

${ }^{18}$ Del Barco, 'Presentación', in La crisis del marxismo, reprinted in Escrituras: filosofía, 283-4.

${ }^{19}$ Del Barco, 'Heidegger y el "misterio" de la técnica', in El abandono de las palabras, 179.

${ }^{20}$ Del Barco, Esencia y apariencia, 65.

${ }^{21}$ Marx, Cuaderno Spinoza, back cover.

${ }^{22}$ Althusser, 'The object of Capital', in Althusser and Balibar, Reading Capital, 102. See also Macherey, Hegel or Spinoza; Balibar, Spinoza and Politics; Tosel, Du matérialisme de Spinoza; and Negri, Savage Anomaly. In Latin America, see especially the work of Chauí, Nervura do real; and Tatián, Spinoza disidente.

${ }^{23}$ Chauí, 'Marx y la democracia', 91.

${ }^{24}$ Balibar, 'Marx, the joker in the pack', 11.

${ }^{25}$ Abensour, Democracy against the State, xlii-xliii and xliv. As Claude Lefort says in an interview with Esteban Molina: 'Contrary to Marx, Machiavelli understands social division as being constitutive of political society and, therefore, as insuperable. The question for Machiavelli was knowing under what conditions the division, let us say the class division, could be expressed or, on the contrary, remained dissimulated, and how to anchor power in a divided polity.' See Lefort, 'La Ciudad dividida', 568.

${ }^{26}$ Althusser, 'Machiavelli's solitude', in Machiavelli and Us, 117.

${ }^{27}$ Colletti, 'Marxism and the dialectic', 9.

${ }^{28}$ Lyotard, Enthusiasm, 22. For a discussion of Kant's importance in the revision of Marx's revolutionary politics in the case of someone like Enrique Dussel, see Bosteels, 'Sobre la teoría de la disolución del Estado', 147-71.

${ }^{29}$ Del Barco, 'Notas para una introducción', in El abandono de las palabras, 15.

${ }^{30}$ Del Barco, 'Hacia el otro Marx', in El otro Marx, 28.

${ }^{31}$ Del Barco, 'Hacia el otro Marx', in El otro Marx, 29-30.

32Del Barco, 'Hacia el otro Marx', in El otro Marx, 29.

${ }^{33}$ Del Barco, 'El "peligro" y lo que salva', in El abandono de las palabras, 25.

${ }^{34}$ Heidegger, 'Brief on "Humanism"', in Pathmarks, 258-9.

${ }^{35}$ Heidegger, 'Letter on 'Humanism"', in Pathmarks, 256.

${ }^{36}$ Heidegger, 'Letter on 'Humanism"', in Pathmarks, 259. 
${ }^{37}$ Del Barco, 'Heidegger y el "misterio" de la técnica', in El abandono de las palabras, 180, 182.

${ }^{38}$ Del Barco, 'Hacia el otro Marx', in El otro Marx, 34.

${ }^{39}$ Del Barco, 'Heidegger y el "misterio" de la técnica', in El abandono de las palabras, 188.

${ }^{40}$ Heidegger, 'Letter on "Humanism"', in Pathmarks, 259.

${ }^{41}$ Del Barco, 'Hacia el otro Marx', in El otro Marx, 33-4.

${ }^{42}$ Del Barco, 'Hacia el otro Marx', in El otro Marx, 40-1.

${ }^{43}$ Del Barco, 'El "peligro" y lo que salva', El abandono de las palabras, 22. See also Del Barco, Alternativas de lo posthumano.

${ }^{44}$ Del Barco, 'El "peligro" y lo que salva', in El abandono de las palabras, 23.

${ }^{45}$ Del Barco, 'El "peligro" y lo que salva', in El abandono de las palabras, $23-4$.

${ }^{46} \mathrm{Del}$ Barco, 'Sobre el problema', in El otro Marx, 43. See also, in a text from the same period, Alain Badiou's reading of the crisis of Marxism: 'What was supposed to be a strategy of the event, a hypothesis regarding the histerias of the social, an organ of interpretation-interruption, a courage of fortune, finally has been presented by way of the economy as giving us a convenient measure of social relationships. In this way Marxism was destroyed by its own history, which is that of its fixion, with an $x$, the history of its fixation into the philosopheme of the political', in Badiou, Can Politics Be Thought?, 33-34. It is significant that this short book has its origin in a presentation, in two sessions, at the Center for Philosophical Research on the Political, organised at the École Normale Supérieure in rue d'Ulm in Paris by Philippe Lacoue-Labarthe and Jean-Luc Nancy, where Balibar and Abensour also presented the first versions of their texts quoted above.

${ }^{47}$ Del Barco, 'El "peligro" y lo que salva', in El abandono de las palabras, 21.

${ }^{48}$ Heidegger, 'Letter on "Humanism"', in Pathmarks,240.

${ }^{49}$ Del Barco, 'Heidegger y el "misterio" de la técnica', in El abandono de las palabras, 171.

${ }^{50}$ Del Barco, 'Crisis de la política', in El abandono de las palabras, 117.

${ }^{51}$ Del Barco, 'Crisis de la política', in El abandono de las palabras, 123.

${ }^{52}$ Del Barco, 'Notas a Desde la línea', in La intemperie sin fin, 151. See also Tatián, Desde la línea, the book in which these 'notes' first appeared as an epilogue.

${ }^{53}$ Del Barco, 'Heidegger y el "misterio" de la técnica', in El abandono de las palabras, 190-1.

${ }^{54}$ Del Barco, 'El "peligro" y lo que salva', in El abandono de las palabras, 30.

${ }^{55}$ Del Barco, 'El "peligro" y lo que salva', in El abandono de las palabras, $30-1$.

${ }^{56}$ Del Barco, 'El "peligro" y lo que salva', in El abandono de las palabras, 31.

${ }^{57}$ Del Barco, 'Notas para una introducción', El abandono de las palabras, 12.

${ }^{58}$ Del Barco, 'El "peligro" y lo que salva', in El abandono de las palabras, 26.

${ }^{59}$ Del Barco, 'Heidegger y el "misterio" de la técnica', in El abandono de las palabras, 193-4. No doubt the most lucid treatment of the question 'What to do?' or 'What is to be done?' after Heidegger continues to be Schürmann, Heidegger on Being and Acting.

${ }^{60}$ Del Barco, 'Heidegger y el "misterio" de la técnica', in El abandono de las palabras, 32.

${ }^{61}$ Derrida, 'Force of law', in Acts of Religion, 242.

${ }^{62}$ Marx, Critique of Hegel's 'Philosophy of Right', 141-2.

\section{Declarations and conflict of interests}

The author declares no conflict of interest with this work.

\section{References}

Abensour, Miguel. Democracy against the State: Marx and the Machiavellian Moment. Translated by Max Blechman and Martin Breaugh. Malden, MA: Polity, 2011.

Althusser, Louis. 'The crisis of Marxism'. Marxism Today (July 1978): 215.

Althusser, Louis. Machiavelli and Us. Edited by François Matheron. Translated by Gregory Elliott. New York: Verso, 1999.

Althusser, Louis. 'El marxismo como teoría "finita"'. In Discutir el Estado: Posiciones frente a una tesis de Louis Althusser, edited by José Aricó, 11-21. Mexico City: Folios, 1982.

Althusser, Louis, and Etienne Balibar. Reading Capital. Translated by Ben Brewster. London: Verso, 1997. 
Badiou, Alain. Can Politics Be Thought? Translated and with an introduction by Bruno Bosteels. Durham, NC: Duke University Press, 2018.

Balibar, Etienne. 'Marx, the joker in the pack (or the included middle)'. Economy and Society 14, no. 1 (1985): 1-27. [CrossRef]

Balibar, Etienne. Spinoza and Politics. Translated by Peter Snowdon. London: Verso, 1998.

Bosteels, Bruno. 'El otro Marx: Filosofía y teoría crítica'. In Sujeto, transmodernidad, descolonización. Debates filosóficos latinoamericanos, edited by Mabel Moraña, 39-68. Frankfurt and Madrid: Iberoamericana/Vervuert, 2018.

Bosteels, Bruno. 'Sobre la teoría de la disolución del Estado: Una política de la finitud'. Escrituras americanas 2, no. 2 (2018): 147-71.

Chaú, Marilena. 'Marx y la democracia (o el joven Marx lector de Spinoza)'. Papel Máquina: Revista de cultura 11 (2017): 73-110.

Chaú, Marilena. Nervura do real: Imanência e liberdade em Espinosa, 2 vols. São Paulo: Companhia das Letras, 1999.

Colletti, Lucio. 'Marxism and the Dialectic'. New Left Review I/93 (1975): 3-29.

Del Barco, Oscar. El abandono de las palabras. Buenos Aires: Centro de Estudios Avanzados, Universidad Nacional de Córdoba, 1994.

Del Barco, Oscar. Alternativas de lo posthumano: textos reunidos. Edited by Pablo Gallardo and Gabriel Livov. Mendoza: Caja Negra, 2010.

Del Barco, Oscar. Escrituras: filosofía. Buenos Aires: Biblioteca Nacional, 2011.

Del Barco, Oscar. Esencia y apariencia en El Capital. Puebla: Universidad Autónoma de Puebla, 1977.

Del Barco, Oscar. La intemperie sin fin. Córdoba: Alción, 2008.

Del Barco, Oscar. 'Observaciones sobre la crisis del marxismo: Respuesta a Paramio y Reverte'. Controversia 2-3 (1979): 12-13.

Del Barco, Oscar. El otro Marx. Buenos Aires: Milena Caserola, 2008.

Del Barco, Oscar. 'Presentación'. In La crisis del marxismo. Puebla: Editorial Universidad Autónoma de Puebla, 1979.

Derrida, Jacques. Acts of Religion. Edited with an Introduction by Gil Anidjar. New York: Routledge, 2002.

Heidegger, Martin. Pathmarks. Edited by William McNeill. Cambridge: Cambridge University Press, 1976.

Lefort, Claude. 'La Ciudad dividida y el sentido del republicanismo. Conversación con Claude Lefort'. In Maquiavelo: lecturas de lo politico, translated by Pedro Lomba, 567-77. Madrid: Trotta, 2010.

Lyotard, Jean-François. Enthusiasm: The Kantian critique of history. Translated by Georges van den Abbeele. Stanford, CA: Stanford University Press, 2009.

Macherey, Pierre. Hegel or Spinoza. Translated by Susan M. Ruddick. Minneapolis: University of Minnesota Press, 2011.

Marx, Karl. Critique of Hegel's 'Philosophy of Right'. Edited with an Introduction by Joseph O'Malley. Translated by Annette Jolin. Cambridge: Cambridge University Press, 1970.

Marx, Karl. Cuaderno Spinoza. Edited and translated by Nicolás González Varela. Barcelona: Montesinos, 2012.

Nancy, Jean-Luc. 'The Forgetting of Philosophy'. In The Gravity of Thought. Translated by François Raffoul and Gregory Recco. Atlantic Highlands, NJ: Humanities Press, 1997.

Nancy, Jean-Luc. La pensée dérobée. Paris: Galilée, 2001.

Nancy, Jean-Luc. The Truth of Democracy. Translated by Pascale-Anne Brault and Michael Naas. New York: Fordham University Press, 2010.

Negri, Antonio. Savage Anomaly: The Power of Spinoza's Metaphysics and Politics. Translated by Michael Hardt. Minneapolis: University of Minnesota Press, 1999.

Schürmann, Reiner. Heidegger on Being and Acting: From Principles to Anarchy. Translated by Christine-Marie Gros in collaboration with the author. Bloomington: Indiana University Press, 1987.

Tatián, Diego. Desde la línea: dimensión política en Heidegger. Córdoba: Alción, 1997.

Tatián, Diego. Spinoza disidente. Buenos Aires: Tinta Limón, 2019.

Tosel, André. Du matérialisme de Spinoza. Paris: Kimé, 1994. 